\title{
PI3K/mTOR/S6K signaling pathway - new players and new functional links
}

\author{
V. V. Filonenko \\ Institute of Molecular Biology and Genetics, NAS of Ukraine \\ 150, Akademika Zabolotnogo Str., Kyiv, Ukraine, 03680 \\ filonenko@imbg.org.ua
}

\begin{abstract}
This review summarizes experimental data related to the studies of PI3K/mTOR/S6K signaling conducted at the department of cell signaling. Analysis of novel S6Ks protein-protein interactions provided valuable information for understanding molecular mechanisms of regulation of S6Ks functional activity and subcellular localization mediated by PKC, CK2 and ROC1 ubiquitin ligase. We discuss the identification and functional analysis of novel isoform of ribosomal protein S6 kinase - S6K2 and of mTOR kinase - mTOR $\beta$, as well as their oncogenic properties. Identification of CoA synthase responsible for last two steps in CoA biosynthesis and characterization of its interactions with S6K1 and other signaling molecules uncovere a potential link between mTOR/S6K signaling pathway and energy metabolism through regulation of CoA biosynthesis. The data concerning new molecular mechanisms of COA synthase regulation are presented.
\end{abstract}

Keywords: PI3K/mTOR/S6K, cell signaling, protein-protein interactions, S6 kinase, CoA synthase.

Most organisms have evolved mechanisms for prompt response to environmental changes by efficiently and accurately altering gene expression and protein biosynthesis. Proteins are produced as a consequence of new mRNA synthesis through transcription regulation, but translation of mRNA into protein is also regulated and often has a defining role during the embryonic development, memory formation and maintenance of normal physiology. Therefore, mammalian cells have evolved elaborate mechanisms for translational control, most of which are sensitive to nutrient availability, cellular energy, hormones and growth factor stimuli.

The PI3K/mTOR/S6K pathway is a main signaling pathway that integrates inputs from at least five major intracellular and extracellular cues - growth factors, stress, energy status, oxygen, and amino acids - to control major processes, including protein and lipid synthesis and autophagy (Figure). Alterations of this signaling occur in many human diseases, including cancer, obesity, type 2 diabetes, neurodegeneration and there

(c) Institute of Molecular Biology and Genetics, NAS of Ukraine, 2013 are significant ongoing efforts to target pharmacologically this pathway (reviewed in [1]).

During almost 15 years research affords of our department were focused on structural and functional organization of mTOR/S6K-dependent signaling pathway. Ribosomal protein S6 kinase 1 and 2 (S6K1/2) together with elongation factor 4 (4EF) binding protein (4EBP) are the best-characterized substrates of mTORC1 complex. S6K1 was identified as an insulin/mitogen-activated protein kinase in mammalian cells, whose major known substrate is the 40S ribosomal subunit protein S6. It is known that the S6K1 gene encodes two proteins, p70S6K1 and p85S6K1, via the use of alternative translational start sites. The predominant form, p70S6K1, is expressed ubiquitously and is localised largely but not exclusively in the cytoplasm, while a nuclear localization sequence (NLS), found within the 23 amino acid Nterminal extension unique to $\mathrm{p} 85 \mathrm{~S} 6 \mathrm{~K} 1$, may target this isoform to the nucleus. Up to the date a number of additional S6K1 substrates have been identified implicating involvement of S6K1 not only in the protein synthesis regulations but in many other processes $[1,2]$. 


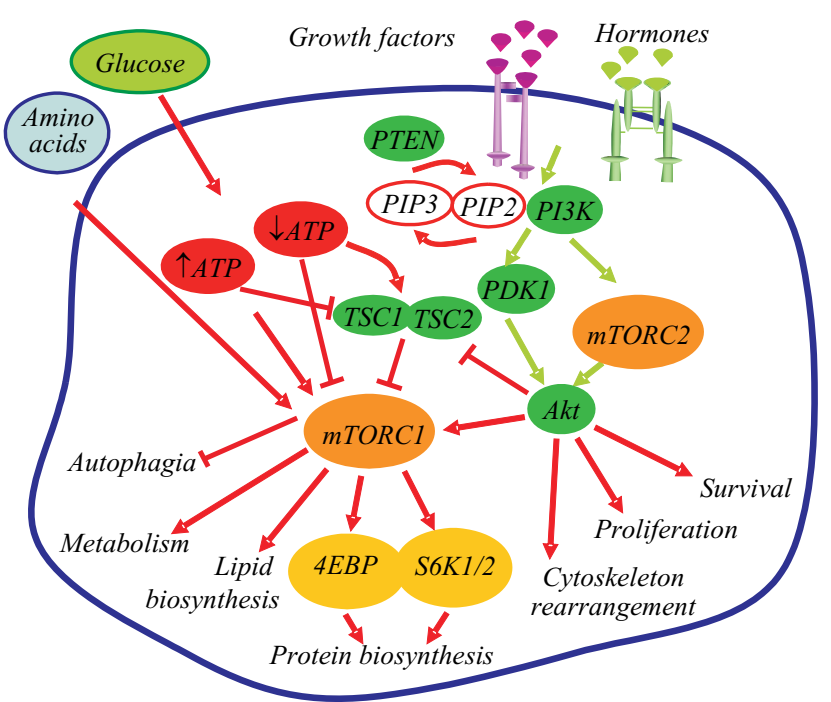

Major components of the PI3K/mTOR/S6K signalling pathway

A novel S6K isoform, termed S6 kinase 2 (S6K2), which has a highly conserved amino acid sequence compared with that of p70/p85 S6 kinase (S6K1) within the catalytic, kinase extension, and autoinhibitory pseudosubstrate domains, was identified almost at the same time by several groups including our group [3-7]. The $S 6 K 2$ gene also utilizes alternative translational start sites to produce two isoforms. The long form (p56S6K2) differs from the short form (p54S6K2) by the presence of a 13 amino acid extension at its N-terminus. Although this $\mathrm{N}$-terminal extension also bears a putative nuclear localization signal, the existence of a nuclear localization signal at the $\mathrm{C}$-terminus of S6K2 means that both isoforms are predominantly localised in the nuclei of quiescent cells. Both S6K1 and S6K2 share a homologous modular organization. The catalytic domains of S6K1 and S6K2 share $83 \%$ identity at the amino acid level. The kinase extension and pseudosubstrate domains are also very similar, and contain several conserved serine and threonine residues critical to the activation of S6K1 and S6K2 that we confirmed applying site directed mutagenesis [8].

Interesting differences we found within the extreme N- and C-terminal regions that could be important for the regulation of these kinases. It is thought that these differences may direct the kinases to distinct compartments (e.g. the NLS found in the S6K2 C-terminus) or to different molecular targets. For instance the $\mathrm{C}$-terminal PDZ binding domain in S6K1 that is absent in S6K2 allows recruitment to the actin cytoskeleton via binding to neurabin. S6K2 meanwhile, contains a proline-rich region in its $\mathrm{C}$-terminus which may facilitate interaction with $\mathrm{SH} 3$ domain- or WW domain-containing molecules [3].

Our further studies revealed differences in kinetics of serum- and fibronectine-induced activation of cytoplasmic (short) isoforms of S6K1 and S6K2 in transiently transfected HEK293. We demonstrated that S6K2 kinase is activated earlier in response to serum and in addition is less sensitive to inhibition of mTOR-dependent phosphorilation/activation by rapamycin, in comparison with S6K1. These differences indicate the existence of alternative signaling mechanisms, involved in the regulation of S6K2 activity and subcellular localization $[9,10]$.

For analysis of S6K1 and S6K2 expression level and kinases subcellular localization we generated a set of monoclonal and polyclonal antibodies specific for $\mathrm{N}$ and C-terminal parts of S6K1/2 [11-13]. According to our data S6K1 and S6K2 have a tissue specific expression profile with the highest level in brain and testis respectively [14]. Analysis of S6Ks expression in tumor cell lines and tumour tissues revealed a sufficiently increased level of S6K1 and S6K2 in breast tumors [15]. These data are in agreement with the finding that the gene encoding S6K1, resides in the chromosomal region $17 \mathrm{q} 22-17 \mathrm{q} 23$, which is often amplified in breast and lung cancers [16].

Immunohistochemical analysis of S6K1 and S6K2 expression in human breast tumors as well as in other tumors such as endometrial and thyroid confirmed an increased level of S6K1/2 in tumour tissues [17-20]. In addition we detected sufficient alterations in S6K1/2 subcellular localization. Nuclear localization of S6K1 and to a greater extent $\mathrm{S} 6 \mathrm{~K} 2$ has been found in breast adenocarcinomas. In 80 and $25 \%$ of breast adenocarcinoma cases nuclear localization of S6K2 and S6K1 correspondently have been revealed [21,22]. The score for endometrial tumours was 18 and $8 \%$ correspondently [23]. Nuclear localization of S6Ks in epithelial cells of normal tissues has not been detected.

The retention of S6K2 in the nuclei of malignant cells may be caused by deregulation of nucleocytoplasmic shuttling and could subsequently affect cell growth and proliferation, and our data suggest that nuclear accumulation of S6Ks (especially S6K2) is a distinguishing feature of the cancer cells. In addition we found 
correlation between nuclear accumulation of S6K2 (but not S6K1) and Ki67 and PCNA expression that indicates involvement of S6K2 in malignant cells growth regulation [22]. In support to this observation using in vitro 3D primary monolayer cell culture of thyrocytes, obtained from undamaged follicles, we demonstrated that down regulation of thyrocyte functional activity (dedifferentiation) caused by the loss of follicle organization was accompanied by subcellular redistribution (increase in nuclear content) of S6K1 and S6K2 [24-26].

We have found, supporting oncogenic functions of $\mathrm{S} 6 \mathrm{~K}$, that increased protein expression levels of S6K2 in both SCLC and NSCLC biopsies appear to correlate with the development of chemoresistance. At the same time these data suggest different functional activity of S6K1 and S6K2. Indeed we identified a novel FGF-2-induced signaling complex comprising $\mathrm{PKC} \varepsilon / \mathrm{BRaf}$ and $\mathrm{S} 6 \mathrm{~K} 2$ but excluding S6K1. The formation of this complex may explain how S6K1 and S6K2 can be guided to different cellular compartments to target distinct substrates despite their high homology within the kinase domains [27].

The possibility of nucleocytoplasmic shuttling has been proposed for both S6K1 and S6K2 based on the presence of N-terminal NLS in S6K1 and two (N- and Cterminal) nuclear localization signals in S6K2. However, the mechanism of its regulation has not been well understood. In our further studies we have proposed a possible mechanism for the regulation of nucleocytoplasmic shuttling of S6K2 by PKC-mediated phosphorylation [28]. The site of phosphorylation was identified as $\mathrm{S} 486$, which is located within the C-terminal nuclear localization signal of S6K2 and has no homologous in S6K1. PKC-mediated phosphorylation at S486 does not affect S6K2 activity but eliminates the function of its nuclear localization signal and causes retention of an activated form of the kinase in the cytoplasm.

To identify novel functional links of S6Ks we have employed the yeast two-hybrid system to search for novel S6K binding partners and used a full length S6K1 as «bait» [29-31]. One of the protein partner identified was regulatory $\beta$ subunit of protein kinase 2 (CK2). Biochemical analysis revealed that catalytical $\alpha$ subunit of CK2 phosphorylated S6K1 at Ser 17, but it did not affect its enzymatic activity. According to the functional studies using cell's models the CK2-mediated S6K1 phosphorylation affects its nucleocytoplasmic shuttling and en- hancers nuclear export. We also provided evidence that nuclear export of S6K1 is mediated by a CRM1-dependent mechanism [31-33].

Another identified protein partner was ROC1 ubiquitin ligase. Our data suggest the involvement of ROC1 in regulation of $\mathrm{S} 6 \mathrm{~K} 1$ and $\mathrm{S} 6 \mathrm{~K} 2$ stability by ubiquitination and subsequent proteasomal degradation. Furthermore, we found that the site(s) of ubiquitination are located in the kinase domain and that the $\mathrm{N}$ - and C-terminal regulatory regions modulate the efficiency of S6Ks ubiquitination. These studies suggest that S6K signaling also could be regulated through the proteasome-mediated turnover of S6Ks [34, 35].

Upstream regulators of S6Ks, such as PDK1 and protein kinase $\mathrm{B}(\mathrm{PKB} / \mathrm{Akt})$, are recruited to the membrane via their pleckstrin homology $(\mathrm{PH})$ or protein-protein interaction domains. However, the mechanism of integration of S6K into a multi-enzyme complex around activated receptor of tyrosine kinases was not clear. Our data indicate that S6 kinase is recruited into a complex with RTKs via Src mediated phosphorylation on tyrosine(s) in response to PDGF or serum [36].

Recently an oncogenic splice isoform of S6K1 (p31) that has no catalytic activity has been identified. Bioinformatical analysis suggests existence of splice form for S6K2 as well. We have confirmed existence of some of them including p110S6K2 form that according to our data has predominantly nuclear localization [37], but functional analysis of novel S6K splice isoforms is in progress.

Among S6K1 interacting proteins identified by the yeast two-hybrid screening one was represented by a number of clones and had unknown functions. Bioinformatical analysis of DNA sequence, molecular cloning and detailed biochemical analysis revealed that this protein mediates the last two steps in CoA biosynthesis via 4'-phosphopantetheine adenylyltransferase and dephospho-CoA kinase activities, and termed as CoA synthase (CoAsy) [38]. Molecular cloning and characterization of CoAsy provided us with necessary reagents required to study the specificity of interaction with S6K1 that was confirmed by alternative approaches [39]. Coenzyme A functions as a carrier of acetyl and acyl groups in living cells and is essential for numerous biosynthetic, energy-yielding, and degradative metabolic pathways. It is estimated that about $4 \%$ of all cellular enzymes 
utilize CoA or its thioester derivatives as substrates. Our study has uncovered a potential link between mTOR/ S6K signaling pathway and energy metabolism that requires $\mathrm{CoA}$ and its thioester derivatives, but its physiological relevance has to be further elucidated.

In our further studies we provided the evidence that $\mathrm{N}$-terminal sequence of CoAsy (amino acids 1-29) exhibits a hydrophobic profile and targets enzyme to mitochondria where the final stages of CoA biosynthesis take place and that activity of CoAsy is regulated by phospholipids of mitochondria membrane [40].

Analysis of CoAsy expression in different tissues revealed unknown before CoAsy $\beta$ isoform enriched in the brain. Molecular cloning confirmed existence of this splice isoform possessing 29 aa extension at the N-terminus [41].

Bioinformatical analysis revealed a number of serine/threonine and tyrosine phosphorylation sites within CoAsy including $N$-terminal extension of CoAsy $\beta$ as well as motifs responsible for protein-protein interactions. It demonstrates that CoAsy could be involved in the complexes with signaling proteins in living cells which may regulate enzymatic activities of CoAsy or vice versa CoAsy may modulate some steps in signal transduction in the cell in currently unknown way. Indeed in our further studies we found that prolin rich region of CoAsy modulates interaction with number of signaling molecules such as tyrosine kinases Fyn and CSK, phospholipase $\mathrm{C} \gamma, \mathrm{p} 85$ regulatory subunit of PI3K [42]. For $\mathrm{p} 85$ we have demonstrated an existence of functional complex of CoAsy on mitochondria. Unexpectedly, significant changes of PI3K signaling pathway activity were observed in experiments with siRNA-mediated CoAsy knockdown providing additional evidence of the role of CoA biosynthetic pathway in signal transduction $[42,43]$.

Further analysis of CoAsy protein-protein interactions, that could be initiated by phosphotyrosines according to the bioinformatical prediction, revealed several signaling molecules. Shp2 protein tyrosine phosphatase is one of them. We have demonstrated that Shp2 mediates CoAsy dephosphorylation that leads to an increase in CoAsy enzymatic phosphopantetheine adenylyltransferase activity. We, therefore, argue that CoAsy is a novel potential substrate of Shp2 phosphatase and phosphorylation of CoAsy at tyrosine residue(s) could represent unrecognized before mechanism of modulation of intracellular CoA level in response to hormonal and/or other extracellular stimuli [44]. According to our data, Syk and Btk tyrosine kinases can modulate CoAsy phosphorylation in vitro and Src kinase in vivo as well.

Taking into account that alterations in PI3K-dependent signaling very often occur at malignant transformation, we analyzed how CoAsy expression affects cell behavior. According to our data increased levels of CoAsy protein have protective effect on cells in conditions of growth factors deprivation and also support anchorage independent growth. Knock down of CoAsy expression in cancer cell line (HepG2) by siRNA application leads to the dramatic decrease in ability of these cells to form colonies in semisolid agarose. Notably, this ability is one of the hallmarks of cellular malignant transformation [45].

For further studies of possible pathways implicated in CoAsy regulation we applied mass spec analysis of CoAsy protein complexes and identified EDC4 (RCD8) protein as a novel binding partner of CoAsy. EDC4 is best known as a central scaffold component of processing bodies implicated in storage and degradation of mRNA. Identification of the protein involved in degradation and storing of mRNA rather than metabolic and/or regulatory enzyme in complex with CoAsy prompted us to speculate about novel mechanisms of CoA biogenesis regulation. We demonstrated that CoAsy/EDC4 complex formation is regulated by growth factors and is affected by cellular stresses. In addition EDC4 strongly inhibited the dephospho-CoA kinase activity of CoAsy in vitro. Transient overexpression of EDC4 decreases cell proliferation but further co-expression of CoAsy diminishes this effect. We believe that EDC4 might contribute to regulation of CoA biosynthesis in addition to its scaffold function in processing bodies [46-48].

One of the main upstream regulators of both S6K1 and $\mathrm{S} 6 \mathrm{~K} 2$ is mTOR kinase that forms two functionally different complexes mTORC1 and mTORC2 (reviewed in [1] and Figure). We provided evidence of existence of the mTOR splicing isoform, mTOR $\beta$, which lacks most of its protein-protein interaction modules, HEAT and FAT, but retains domains responsible for FRB, protein kinase activity, and regulation (RD and FATC) [49, 50]. Importantly, mTOR $\beta$ could form complexes in vivo with Raptor and Rictor, which are known companions 
of full-length mTOR (mTOR $\alpha)$. Also, it readily phosphorylates characterized mTOR $\beta$ substrates, S6K1, $\mathrm{PKB} / \mathrm{Akt}$, and 4EBP1, in vitro. In contrast to $\mathrm{mTOR} \alpha$, mTOR $\beta$ has the potential to shorten considerably the G1 phase of the cell cycle and to stimulate cell proliferation. Significantly, overexpression of mTOR $\beta$ transforms immortal cells and is tumorigenic in nude mice.

Our studies suggest that the regulation of cell proliferation via the mTOR pathway could be mediated by mTOR $\beta$, which acts as a protooncogene and therefore could be a candidate for future anticancer drug discovery $[49,50]$.

The key upstream regulator of $\mathrm{mTORC} 1$ is heterodimer consisting of tuberous sclerosis 1 (TSC1; also known as hamartin) and TSC2 (also known as tuberin) that functions as a GTPase-activating protein (GAP) for the Ras homolog enriched in brain (Rheb) GTPase. The GTP-bound form of Rheb directly interacts with mTORC1 and strongly stimulates its kinase activity. In turn activity of TSC $1 / 2$ complex is regulated by multiple phosphorylations of TSC2 mediated by several kinases, such as PKB/Akt, AMP-activated kinase (AMPK), ERK, MK2 and RSK1. However so far, very little is known about the molecular mechanisms of TSC2 dephosphorylation. In the yeast two-hybrid screening, we have identified a number of potential TSC 2 binding partners including a protein phosphatase 5 (PP5) [51- 52]. We provided the evidence that the interaction between TSC2 and PP5 also occurs in mammalian cells and found that this interaction is stronger in exponentially growing and serum stimulated cells when compared to serum starved cells.

In addition, we demonstrated that PP5 dephosphorylates specifically TSC2 at sites, associated with its activation via AMP kinase (AMPK) pathway. Taken together, these results suggest that PP5 exerts negative regulation on TSC1/2 function through dephosphorylation of AMPK-mediated sites and in turn positively regulates mTOR activity [53].

As it was mentioned above PI3K/mTOR pathway is a major integrator of intracellular and extracellular inputs. PI3 kinase is a main TORC1 and mTORC2 regulator facilitating signals from mitogenic stimuli. PI3K is located close to the cell membrane and interacts directly or through IRS protein with the intracellular domains of growth factor's and hormone's receptors. Whi- le the mechanism of PI3K activation signaling pathway by extracellular stimuli has become relatively well understood, much less is known about negative regulation of PI3K itself that should affect functional activity of all pathway. Collaboration of several research groups made possible identification of adaptor protein Rukl, which forms complexes with the PI3-kinase holoenzyme in vitro and in vivo [54]. This interaction involves the proline-rich region of Ruk and the $\mathrm{SH} 3$ domain of the $\mathrm{p} 85 \mathrm{a}$ regulatory subunit of the PI3 kinase. In contrast to many other adaptor proteins that activate PI3 kinase, interaction with Rukl substantially inhibits the lipid kinase activity of the enzyme. Our data provide evidence for the existence of a negative regulator of the PI3 kinase signaling pathway that is essential for maintaining cellular homeostasis.

A lipid phosphatase PTEN also negatively regulates PI3K pathway by dephosphorylating the PI (3, 4, 5) $\mathrm{P} 3$ in $\mathrm{D} 3$ position, leading to the suppression of cell growth and other PI3K/Akt-dependent processes. It is logical that PTEN is functioning as a tumor suppressor and is frequently deleted or mutated in many human advanced cancers [55]. For evaluation of PTEN regulatory mechanisms we applied the yeast two-hybrid screening and identified a number of protein partners such as MSP58, FABP4, IFN $\gamma$ R1, DNA J homolog, and eukaryotic translation elongation factor 1 alpha 1-like (prostate tumor-inducing protein 1) [56]. In more details we investigate the interaction between PTEN and FABP4 [56-58]. FABP4 is a known marker of terminal adipocytes differentiation with tissue-specific expression in adipocytes and macrophages. It transfers free fatty acids between cellular compartments and is reported to be associated with metabolic syndrome, obesity, and atherosclerosis. Since mice deficient in FABP4 and its homolog FABP5 were protected from high fat diet-induced metabolic syndrome, and display improved insulin sensitivity, both proteins have been suggested as potential therapeutic targets for drug development [59]. From the other side it is known that PTEN involved into the regulation of FABP4 and other adipocyte-specific genes at the level of transcription. Altogether our data suggest a possible link between PTEN function and lipid metabolism and adipogenesis, but physiological significance of PTEN-FABP4 interaction remains to be investigated. 
Conclusion. In summary our data significantly extend our knowledge about PI3K/mTOR/S6K signaling. Shortly, we identified and characterized a novel isoform of ribosomal protein S6 kinase - S6K2 that shares a high level of homology with known S6K1 isoform. We proposed that these isoforms may have similar and different functions with S6K1 that was further confirmed by other researches.

So far, a number of S6K substrates, other than S6 protein, are identified. Most of them are common for both kinases but some are specific only for particular S6K isoform (reviewed in [2]).

Our data suggest that both isoforms are implicated in cell malignant transformation and are overexpressed in numerous tumors. At the same time we demonstrated that nuclear accumulation S6K in tumor cells could be a hallmark of malignant transformation suggesting that modulation of S6K $1 / 2$ subcellular localization as well as S6K1/2 activity could be an effective approach in cancer treatment.

We proposed molecular mechanisms of nucleocytoplasmic shuttling of S6Ks mediated by PKC-dependent phosphorylation (for S6K2) and CK2-dependent phosphorylation (for S6K1). Analysis of novel S6K protein partners revealed the novel mechanism of regulation of S6K1/2 stability facilitated by ROC1 ubiquitin ligase. Our studies uncovered a potential link between $\mathrm{mTOR} / \mathrm{S} 6 \mathrm{~K}$ signaling pathway and energy metabolism through $\mathrm{CoA}$ and its thioester derivatives by identifying CoA synthase, the enzyme that is responsible for last two steps in CoA biosynthesis and involved in complex formation with S6K1 and other signaling molecules. We provided evidence that regulation of CoAsy activity is a second (after regulation of pantothenate kinase activity) regulatory point in CoA biosynthesis that could be mediated by the protein of processing bodies EDC and Shp2 phosphatase. At the same time we have demonstrated that alterations in CoA biosynthesis significantly affect PI3K/mTOR signaling and cell behavior suggesting that CoAsy could be a novel target for anticancer therapy.

We claim that the regulation of cell proliferation via the mTOR pathway could be mediated by newly identified mTOR isoform - mTOR $\beta$, which acts as a protooncogene and therefore could be also a candidate for future anticancer drug discovery.

\section{В. В. Філоненко}

Сигнальний шлях PI3K/mTOR/S6K - нові гравці та нові функціональні зв'язки

\section{Резюме}

В огляді представлено експериментальні результати дослідження сигнального иляху PI3K/mTOR/S6K, отримані у відділі сигнальних систем клітини. Аналіз нещчодавно виявлених білково-білкових взаємодій S6K надає важливу інформаџію для розуміння молекулярних механізмів регуляиї функиіональної активності S6K та ї̈ субклітинної локалізачії за участі PKC, CK2 і убіквитинлігази ROC1. Обговорюються дані шзодо ідентифікаиії і функиіонального аналізу нової ізоформи кінази рибосомного білка S6 - S6K2 і mTORкінази - mTORß, а також їхніх онкогенних властивостей. Ідентифікаиія СоА-синтази, щуо є відповідальною за два останніх етапи біосинтезу СоA, а також характеристика ї̈ взаємодї з S6K1 та іншими сигнальними молекулами свідчать про існування потенційного зв'язку між сигнальним шляхом mTOR/S6K та енергетичним метаболізмом, опосередкованого регуляиією біосинтезу СоА. Наведено дані стосовно виявлених молекулярних механізмів регуляиії активності синтази СоА.

Ключові слова: PI3K/mTOR/S6K, сигнальні системи клітини, білково-білкові взаємодії, кіназа S6, синтаза СоA.

\section{В. В. Филоненко}

Сигнальный путь PI3K/mTOR/S6K - новые игроки и новые функциональные связи

Резюме

В обзоре представлены экспериментальные результаты исследования сигнального пути PI3K/mTOR/S6K, полученные в отделе сигнальных систем клетки. Анализ вновь выявленных белково-белкових взаимодействий S6K дает иенную информацию для понимания молекулярных механизмов регуляции функциональной активности S6К и ее субклеточной локализации при участии $P K C$, CK2 и убиквитинлигазы ROC1. Обсуждаются данные, касаюшиеся идентификачии и функиионального анализа новой изоформы киназы рибосомного белка S6 - S6K2 и mTOR киназы-mTOR, а также их онкогенных свойств. Идентификация СоА-синтазы-фермента, отвечающего за два последних этапа биосинтеза Со А, и анализ ее взаимодействия с S6K1 и другими сигнальными молекулами свидетельствуют о существовании потенциальной связи между сигнальным путем тTOR/S6K и энергетическим метаболизмом, опосредованным регулячиией биосинтеза СоА. Приведены данные о выявленных молекулярных механизмах регуляции синтазы СоА.

Ключевые слова: PI3K/mTOR/S6K, сигнальные системы клетки, белково-белковые взаимодействия, киназа S6, синтаза СоA.

\section{REFERENCES}

1. Laplante M., Sabatini D. M. mTOR signaling in growth control and disease // Cell.-2012.-149, N 2.-P. 274-293.

2. Fenton T. R., Gout I. T. Functions and regulation of the $70 \mathrm{kDa}$ ribosomal S6 kinases // Int. J. Biochem. Cell. Biol.-2011.-43, N 1.-P. 47-59.

3. Gout I., Minami T., Hara K., Tsujishita Y., Filonenko V., Waterfield M. D., Yonezawa K. Molecular cloning and characterization of a novel p70 S6 kinase, p70 kinase beta containing a prolinrich region // J. Biol. Chem.-1998.-273, N 46.-P. 30061-30064. 
4. Koh H., Jee K., Lee B., Kim J., Kim D., Yun Y. H., Kim J. W., Choi $H$. S., Chung J. Cloning and characterization of a nuclear S6 kinase. S6 kinase-related kinase (SRK); a novel nuclear target of Akt // Oncogene.-1999.-18, N 36.-P. 5115-5119.

5. Lee-Fruman K. K., Kuo C. J., Lippincott J., Terada N., Blenis J. Characterization of S6K2, a novel kinase homologous to S6K1 // Oncogene.-1999.-18, N 36.-P. 5108-5114.

6. Saitoh M., ten Dijke P., Miyazono K., Ichijo H. Cloning and characterization of $\mathrm{p} 70$ (S6K beta) defines a novel family of p70 S6 kinases // Biochem. Biophys. Res. Commun.-1998.-253, N 2.P. 470-476.

7. Shima H., Pende M., Chen Y., Fumagalli S., Thomas G., Kozma $S$. C. Disruption of the $\mathrm{p} 70(\mathrm{~s} 6 \mathrm{k}) / \mathrm{p} 85(\mathrm{~s} 6 \mathrm{k})$ gene reveals a small mouse phenotype and a new functional S6 kinase // EMBO J.1998.-17, N 22.-P. 6649-6659.

8. Valovka T. I., Gout I. T., Filonenko V. V. Effect of point mutations of regulatory aminoacids residues and $\mathrm{N}$ - and $\mathrm{C}$-terminal deletions of S6K1 i S6K2 on kinase activity // Biopolym. Cell.2005.-21, N 1.-P. 42-47.

9. Valovka T. I., Fiionenko V. V., Palchevsky S. S., Velikiy M. M., Drobot L. B., Waterfield M., Matsuka G. Kh., Gout I. T. Functional and regulatory properties of p70S6 kinase $\beta$ // Biopolym. Cell.-1999.-15, N 5.-P. 415-421.

10. Val'ovka T. I., Filonenko V. V., Velykyi M. M., Drobot L. B., Voterfill M., Matsuka H. Kh., Hut I. T. Features of fibronectin-dependent activation of ribosomal protein S6 kinase (S6K1 and S6K2) // Ukr. Biokhim. Zh.-2000.-72, N 3.-P. 31-37.

11. Pogrebnoy P. V., Kukharenko A. P., Tykhonkova I. A., Pal'chevskii S. S., Savinskayya L. A., Pogrebnaya A. P., Valevka T. I., Markeeva N. V., Soldatkina M. A., Matsuka G. K., Gout I. T., Filonenko $V$. $V$. Generation and characterization of monoclonal antibodies to P70S6 kinase alpha // Exp. Oncol.-1999.-21, N 3-4.P. 232-238.

12. Savinska L., Skorokhod O., Klipa O., Gout I., Filonenko V. Development of monoclonal antibodies specific to ribosomal protein S6 kinase 2 // Hybridoma.-2012.-31, N 4.-P. 289-294.

13. Savinska L. O., Klipa O. M., DemchukN. O., Ovcharenko G. V., Malanchuk O. M., Tykhonkova I. O., Palchevskyy S. S., Filonenko $V$. $V$. Generation of monoclonal antibodies specific to ribosomal protein S6 kinase $1 / /$ Biopolym. Cell.-2012.-28, N 6.P. 424-428.

14. Savinska L. O., Kijamova R. G., Pogrebnoy P. V., Ovcharenko G. V., Gout I. T., Filonenko V. V. Comparative characterization of S6 kinase $\alpha$ and $\beta$ isoforms expression in mammalian tissues // Biopolym. Cell.-2001.-17, N 5.-P. 374-379.

15. Savinskaya L. A., Usenko V. S., Lyzogubov V. V., Pogrebnoy P. V., Pal'chevsky S. S., Ovcharenko G. V., Cheshuk V. S., Gout I. T., Matsuka G. Kh., Filonenko V. V. P 70 S6 kinase $\alpha$ and $\beta$ isoforms expression in cell lines and breast tumors // Biopolym. Cell.-2003.-19, N 1.-P. 64-70.

16. Barlund M., Monni O., Kononen J., Cornelison R., Torhorst J., Sauter G., Kallioniemi OLLI-P., Kallioniemi A. Multiple genes at 17 q23 undergo amplification and overexpression in breast cancer // Cancer Res.-2000.-60, N 19.-P. 5340-5344.

17. Savinska L. O., Lyzogubov V. V., Usenko V. S., Ovcharenko G. V., Gorbenko O. N., Rodnin M. V., Vudmaska M. I., Pogribniy P. V., Kyyamova R. G., Panasyuk G. G., Nemazanyy I. O., Malets M. S., Palchevskyy S. S., Gout I. T., Filonenko V. V. Immuno- histochemical analysis of S6K1 and $\mathrm{S} 6 \mathrm{~K} 2$ expression in human breast tumors // Exp. Oncol.-2004.-26, N 1.-P. 24-30.

18. Lytvyn D. I., Dudchenko T. M., Lyzogubov V. V., Usenko V. S., Nespryadko S. V., Vinnitskaya A. B., Vorobyova L. I., Pal'chevskiy S. S., Filonenko V. V., Pogrebnoy P. V. Expression of $\alpha$ - and $\beta$-isoform of p70S6 kinase in human endometrial tumors // Exp. Oncol.-2003.-25, N 4.-P. 274-278.

19. Lysogubov V. V., Usenko V. S., Khojaenko Yu. S., Lytvyn D. I., Soldatkina M. A., Rodnin N. V., Filonenko V. V., Pogrebniy P. $V$. Immunohistochemical analysis of p70S6 kinase $\alpha$ in human thyroid tissue upon pathology // Exp. Oncol.-2003.-25, N 4.P. 304-306.

20. Lytvyn D. I., Dudchenko T. N., Filonenko V. V., Savinskaya L. A., Pogrebnoy P. V. Expression of p70S6 kinase in Guerin's carcinoma cells upon tumor development // Exp. Oncol.-2003.-25, N 2.-P. 149-151.

21. Filonenko V. V., Tytarenko R., Azatjan S. K., Savinska L. O., Gaydar Y. A., Gout I. T., Usenko V. S., Lyzogubov V. V. Immunohistochemical analysis of S6K1 and S6K2 localization in human breast tumors // Exp. Oncol.-2004.-26, N 4.-P. 294-299.

22. Lyzogubov V., Khozhaenko Y., Usenko V., Antonjuk S., Ovcharenko $G$., Tikhonkova $I$., Filonenko $V$. Immunohistochemical analysis of $\mathrm{Ki}-67$, PCNA and S6K1/2 expression in human breast cancer // Exp. Oncol.-2005.-27, N 2.-P. 141-144.

23. Lyzogubov V. V., Lytvyn D. I., Dudchenko T. M, Lubchenko N V., Pogrybniy P. V., Nespryadko S. V., Vinnitska A. B., Usenko $V$. S., Gout I. T., Filonenko V. V. Imunnohistochemical study of S6K1 and S6K2 expression in human endometrial adenocarcinomas // Exp. Oncol.-2004.-26, N 4.-P. 287-293.

24. Khoruzhenko A., Kukharchuk V., Cherednyk O., Tykhonkova I., Ovcharenko G., Malanchuk O., Filonenko V. Monoclonal antibodies to Ki-67 protein suitable for immunohistochemical analysis // Hybridoma (Larchmt).-2010.-29, N 4.-P. 301-304.

25. Khoruzhenko A. I., Cherednyk O. V., Filonenko V. V. Subcellular localization of S6K1 and S6K2 forms of ribosomal protein S6 kinase in rat thyrocytes under conditions of two- and threedimensional culture // Biopolym. Cell.-2008.-24, N 6.P. 470-475.

26. Khoruzhenko A. I., Cherednyk O. V., Filonenko V. V. Subcellular localization of S6K1 and S6K2 forms of ribosomal protein S6 kinase in primary monolayer culture of rat thyrocytes // Biopolym. Cell.-2008.-24, N 1.-P. 35-40.

27. Pardo O. E., Wellbrock C., Khanzada U. K., Aubert M., Arozarena I., Davidson S., Bowen F., Parker P. J., Filonenko V. V., Gout I. T., Sebire N., Marais R., Downward J., Seckl M. J. FGF-2 protects small cell lung cancer cells from apoptosis through a complex involving PKC epsilon, B-Raf and S6K2 // EMBO J.-2006.25, N 13.-P. 3078-3088.

28. Valovka T., Verdier F., Cramer R., Zhyvoloup A., Fenton T., Rebholz H., Wang M. L., Gzhegotsky M., Lutsyk A., Matsuka G., Filonenko V., Wang L., Proud C. G., Parker P. J., Gout I. T. Protein kinase $C$ phosphorylates ribosomal protein S6 kinase beta II and regulates its subcellular localization // Mol. Cell. Biol.2003.-23, N 3.-P. 852-863.

29. Panasyuk G., Nemazanyy I., Filonenko V., Zhyvoloup A. Largescale yeast transformation in low-percentage agarose medium // Biotechniques.-2004.-36, N 1.-P. 40-42.

30. Zhyvoloup O. M., Nemazanyy I. O., Pobigailo N. V., Panasyuk G. G., Palchevskyy S. S., Kuharenko O. P., Savinska L O., Ovcharenko G. V., Vudmaska M. I., Gout I. T., Matsuka G. Kh., Filonenko $V$. $V$. Use of yeast two-hybrid system in search of S6K1 and S6K2 binding partners // Biopolym. Cell.-2002.-18, N 2,-102-109.

31. Panasyuk G. G., Nemzanyy I. O., Zhyvoloup A. M., Filonenko V. $V$., Gout I. T. The beta subunit of casein kinase 2 as a novel binding partner of the ribosomal protein S6 kinase $1 / /$ Biopolym. Cell.-2005.-21, N 5.-P. 407-412.

32. Panasyuk G., Nemazanyy I., Zhyvoloup A., Bretner M., Litchfield D. W., Filonenko V., Gout I. T. Nuclear export of S6K1 II is re- 
gulated by protein kinase CK2 phosphorylation at Ser-17 //J Biol. Chem.-2006.-281, N 42.-P. 31188-31201.

33. Panasyuk G. G., Nemazanyy I. O., Zhyvoloup A. M., Filonenko $V$. V., Gout I. T. Regulation of S6K1 subcellular localization by Casein kinase $2 / /$ Biopolym. Cell.-2006.-22, N 1.-P. 82-84.

34. Wang M. L., Panasyuk G., Gwalter J., Nemazanyy I., Fenton T., Filonenko V., Gout I. Regulation of ribosomal protein S6 kinases by ubiquitination // Biochem. Biophys. Res. Commun.-2008.369, N 2.-P. 382-387.

35. Panasyuk G., Nemazanyy I., Filonenko V., Gout I. Ribosomal protein $\mathrm{S} 6$ kinase 1 interacts with and is ubiquitinated by ubiquitin ligase ROC1 // Biochem. Biophys. Res. Commun.-2008.369, N 2.-P. 339-343.

36. Rebholz H., Panasyuk G., Fenton T., Nemazanyy I., Valovka T., Flajolet M., Ronnstrand L., Stephens L., West A., Gout I. T. Receptor association and tyrosine phosphorylation of S6 kinases // FEBS J.-2006.-273, N 9.-P. 2023-2036.

37. Panasyuk G. G., Nemazanyy I. O., Gout I. T., Filonenko V. V. Identification of endogeneous isoform of ribosomal protein S6 kinase - S6K2 // Biopolym. Cell.-2005.-21, N 3.-P. 293-295.

38. Zhyvoloup A., Nemazanyy I., Babich A., Panasyuk G., Pobigailo N., Vudmaska M., Naidenov V., Kukharenko O., Palchevskii S., Savinska L., Ovcharenko G., Verdier F., Valovka T., Fenton T., Rebholz H., Wang M. L., Shepherd P., Matsuka G., Filonenko V., Gout I. T. Molecular cloning of CoA synthase. The missing link in CoA biosynthesis // J. Biol. Chem.-2002.-277, N 25.P. 22107-22110.

39. Nemazanyy I., Panasyuk G., Zhyvoloup A., Panayotou G., Gout I. T., Filonenko V. Specific interaction between S6K1 and CoA synthase: a potential link between the mTOR/S6K pathway, CoA biosynthesis and energy metabolism // FEBS Lett.-2004.-578, N 3.-P. 357-362.

40. Zhyvoloup A., Nemazanyy I., Panasyuk G., Valovka T., Fenton T., Rebholz H., Wang M. L., Foxon R., Lyzogubov V., Usenko V., Kyyamova R., Gorbenko O., Matsuka G., Filonenko V., Gout I. $T$. Subcellular localization and regulation of Coenzyme A Synthase // J. Biol. Chem.-2003.-278, N 50.-P. 50316-50321.

41. Nemazanyy I., Panasyuk G., Breus O., Zhyvoloup A., Filonenko V., Gout I. T. Identification of a novel CoA synthase isoform, which is primarily expressed in the brain // Biochem. Biophys. Res. Commun.-2006.-341, N 4.-P. 995-1000.

42. Breus O. S., Panasyuk G. G., Gout I. T., Filonenko V. V., Nemazanyy $I$. $O$. Proline rich regions of coenzyme A synthase $\alpha$ and $\beta$ interact with $\mathrm{SH} 3$ domains of signaling proteins in vitro // Biopolym. Cell.-2008.-24, N 2.-P. 123-128.

43. Breus O., Panasyuk G., Gout I. T., Filonenko V., Nemazanyy I. CoA synthase is in complex with $\mathrm{p} 85$ alphaPI3K and affects PI3K signaling pathway // Biochem. Biophys. Res. Commun.-2009.385, N 4.-P. 581-585.

44. Breus O., Panasyuk G., Gout I. T., Filonenko V., Nemazanyy I. CoA Synthase is phosphorylated on tyrosines in mammalian cells, interacts with and is dephosphorylated by Shp2PTP // Mol. Cell. Biochem.-2010.-335, N 1-2.-P. 195-202.

45. Breus O S., Nemazanyy I. O., Gout I. T., Filonenko V. V., Panasyuk $G$. G. CoA Synthase influences adherence-independent growth and survival of mammalian cells in vitro // Biopolym. Cell.-2009.-25, N 5.-P. 384-389.
46. Gudkova D., Panasyuk G., Nemazanyy I., Zhyvoloup A., Monteil P., Filonenko V., Gout I. EDC4 interacts with and regulates the dephospho-CoA kinase activity of CoA synthase // FEBS Lett.2012.-586, N 20.-P. 3590-3595.

47. Gudkova D. O., Panasyuk G. G., Nemazanyy I. O., Filonenko V. $V$. PI3K/mTor-dependent signaling pathway as a possible regulator of processing body assembly // Biopolym. Cell.-2011.-27, N 5.-P. 369-372.

48. Gudkova D. O., Panasyuk G. G., Nemazanyy I. O., Filonenko V. $V$. Novel antibodies against RCD-8 as a tool to study processing bodies // Biopolym. Cell.-2010.-26, N 6.-P. 512-516.

49. Panasyuk G., Nemazanyy I., Zhyvoloup A., Filonenko V., Davies. D, Robson M., Pedley R. B., Waterfield M., Gout I. The mTORbeta splicing isoform promotes cell proliferation and tumorigenesis // J. Biol. Chem.-2009.-284, N 45.-P. 30807-30814.

50. Skorokhod O., Nemazanyy I., Breus O., Filonenko V., Panasyuk $G$. Generation and characterization of monoclonal antibodies to TDRD7 protein // Hybridoma (Larchmt).-2008.-27, N 3.P. 211-216

51. Malanchuk O. M., Palchevskyy S. S., Pozur V. K., Gout I. T., Filonenko $V$. $V$. Interaction of serine/threonine protein phosphatase 5 (PP5) with the protein product of tumour suppressor gene Tsc2 // Biopolym. Cell.-2007.-23, N 4.-P. 318-323.

52. Malanchuk O., Palchevskyy S., Ovcharenko G., Gwalter J., Pozur V., Gout I., Filonenko V. Generation and characterization of monoclonal antibodies against tuberous sclerosis complex $2 / /$ Hybridoma (Larchmt).-2007.-26, N 4.-P. 259-266.

53. Malanchuk O. M., Palchevskyy S. S., Filonenko V. V. Dephosphorylation of tuberous sclerosis complex 2 by serine/threonine protein phosphatase 5 // Biopolym. Cell.-2008.-24, N 2.P. 176-179.

54. Gout I., Middleton G., Adu J., Ninkina N. N., Drobot L. B., Filonenko V., Matsuka G., Davies A. M., Waterfield M., Buchman V. $L$. Negative regulation of PI 3-kinase by Ruk, a novel adaptor protein // EMBO J.-2000.-19, N 15.-P. 4015-4025.

55. DeBerardinis R. J., Lum J. J., Hatzivassiliou G., Thompson C. B. The biology of cancer: metabolic reprogramming fuels cell growth and proliferation // Cell Metab.-2008.-7, N 1.-P. 11-20.

56. Gorbenko O. M., Panayotou D., Volkova D. D., Zhyvoloup O. M., Kukharenko O. P., Gout I. T., Filonenko V. V. Interaction of fatty acid transporting protein FABP4 with phosphatase PTEN // Biopolym. Cell.-2006.-22, N 3.-P. 217-224.

57. Gorbenko O., Panayotou G., Zhyvoloup A., Volkova D., Gout I. Filonenko $V$. Identification of novel PTEN-binding proteins: PTEN interections with fatty acid binding protein FABP4 // Mol. Cell. Biochem.-2010.-337, N 1-2.-P. 299-305.

58. Gorbenko O., Filonenko V., Gout I. Generation and characterization of monoclonal antibodies against FABP4 // Hybridoma (Larchmt).- 2006.-25, N 2.-P. 86-90.

59. Uysal K. T., Scheja L., Wiesbrock S. M., Bonner-Weir S., Hotamisligil G. S. Improved glucose and lipid metabolism in genetically obese mice lacking aP2 // Endocrinology.-2000.-141, N 9.P. 3388-3396. 